\title{
Meningkatkan keterampilan guru dalam membuat rencana pelaksanaan pembelajaran tematik melalui workshop
}

\section{Improve the skills of teachers in making thematic learning implementation plans through workshops}

\author{
Suwardi ${ }^{1}$ \\ ${ }^{1}$ SDN 1 Landasan Ulin Utara \\ Email: suwardiberlina@yahoo.co.id ${ }^{1}$
}

\section{INFO ARTIKEL}

Diterima : 30 April 2021

Disetujui : 27 Mei 2021

Tersedia secara Online Mei 2021

\section{Alamat Korespondensi: \\ Suwardi \\ SDN 1 Landasan Ulin Utara \\ Jln. Sukamara 006/002, Landasan Ulin \\ Utara, Kec. Liang Anggang, Kota \\ Banjarbaru Prov. Kalimantan Selatan \\ E-mail: suwardiberlina@yahoo.co.id}

\section{ABSTRAK}

Peserta didik yang berada pada sekolah dasar kelas satu, dua, dan tiga berada pada rentangan usia dini. Pada usia tersebut seluruh aspek perkembangan kecerdasan seperti IQ, EQ, dan SQ tumbuh dan berkembang sangat luar biasa dan melihat segala sesuatu sebagai satu keutuhan (holistik) mampu memahami hubungan antara konsep secara sederhana. Proses pembelajaran masih bergantung kepada objek-objek konkrit dan pengalaman yang dialami secara langsung. Pelaksanaan kegiatan pembelajaran di SD kelas I-III untuk setiap mata pelajaran dilakukan secara terpisah, misalnya PKn 2 jam pelajaran, IPS 2 jam pelajaran, dan Bahasa Indonesia 2 jam pelajaran. Dalam pelaksanaan kegiatannya dilakukan secara murni mata pelajaran yaitu hanya mempelajari standar kompetensi dan kompetensi dasar yang berhubungan dengan mata pelajaran itu. Sesuai dengan tahapan perkembangan anak sebagai suatu keutuhan (holistik), pembelajaran mata pelajaran secara terpisah akan menyebabkan kurang mengembangkan anak untuk berpikir holistik dan membuat kesulitan bagi peserta didik. Apakah dengan workshop dapat meningkatkan keterampilan guru dalam membuat rencana pelaksanaan pembelajaran tematik?; Apakah dengan workshop dapat meningkatkan aktivitas guru dalam membuat rencana pelaksanaan pembelajaran tematik? Meningkatkan keterampilan guru dalam membuat rencana pelaksanaan pembelajaran tematik dilakukan kegiatan workshop; Untuk mengetahui aktivitas guru dalam membuat rencana pelaksanaan pembelajaran tematik dilakukan dengan observasi kegiatan guru dalam kegiatan workshop.

Kata kunci: siswa, kegiatan guru, lokakarya.

Students who are in grade one, two, and three elementary schools are in the early age range. At that age, all aspects of intelligence development such as IQ, EQ, and $S Q$ grow and develop in a very extraordinary way and seeing everything as a whole (holistic) is able to understand the relationship between concepts in a simple way. The learning process still depends on concrete objects and experiences directly experienced. The implementation of learning activities in SD grades I-III for each subject is carried out separately, for example Civics 2 hours of lessons, 2 hours of social studies, and 2 hours of Indonesian Language. In the implementation of activities carried out purely in subjects, namely only studying the competency standards and basic competencies related to these subjects. In accordance with the stages of child development as a wholeness (holistic), learning separate subjects will cause less development of children to think holistically and make it difficult for students. Can the workshop improve the skills of teachers in making plans for implementing 
thematic learning ?; Can the workshop increase teacher activity in making plans for implementing thematic learning? Improve the skills of teachers in making plans for implementing thematic learning workshops; To find out the activities of teachers in making plans for implementing thematic learning, it is carried out by observing teacher activities in workshop activities.

Key words: students, teacher activities, workshop.

\section{PENDAHULUAN}

Peraturan Menteri Pendidikan Nasional Republik Indonesia Nomor 22 Tahun 2006 tentang Standar Isi Kurikulum dan Nomor 41 Tahun 2007 tentang Standar Proses Pembelajaran Untuk Satuan pendidikan Dasar dan Menengah menyebutkan bahwa dalam proses pembelajaran harus berintikan kegiatan eksplorasi, elaborasi, dan konfirmasi. Pembelajaraan matematika yang efektif tercermin dari rumusan Rancangan Pembelajaran Matematika yang memenuhi tuntutan kurikulum berdasarkan Standar Isi maupun Standar Proses. Rancangan Pembelajaran Matematika dituangkan secara tertulis dalam bentuk Rencana Pelaksanaan pembelajaran (RPP).

Rencana Peleksanaan Pembelajaran (RPP) pada hakikatnya merupakan perencanaan jangka pendek untuk memperkirakan atau memproyeksikan tentang apa yang akan dilakukan dalam kegiatan pembelajaran di kelas. RPP dijabarkan dari silabus untuk mengarahkan kegiatan belajar siswa dalam upaya mencapai KD. Komponen RPP meliputi: Identitas mata pelajaran, Standar Kompetensi, Kompetensi Dasar, Indikator Pencapaian Kompetensi, tujuan Pembelajaran, Materi ajar, Alokasi Waktu, Metode Pembelajaran. Kegiatan Pembelajaran meliputi: Pendahuluan (Kegiatan Awal), Kegiatan Inti, Penutup (Kegiatan Akhir), Penilaian Hasil Belajar, serta Media dan sumber belajar.

Peserta didik yang berada pada sekolah dasar kelas satu, dua, dan tiga berada pada rentangan usia dini. Pada usia tersebut seluruh aspek perkembangan kecerdasan seperti IQ, EQ, dan SQ tumbuh dan berkembang sangat luar biasa. Pada umumnya tingkat perkembangan masih melihat segala sesuatu sebagai satu keutuhan (holistik) serta mampu memahami hubungan antara konsep secara sederhana. Proses pembelajaran masih bergantung kepada objek-objek konkrit dan pengalaman yang dialami secara langsung.

Pelaksanaan kegiatan pembelajaran di SD kelas I-III untuk setiap mata pelajaran dilakukan secara terpisah, misalnya PKn 2 jam pelajaran, IPS 2 jam pelajaran, dan Bahasa Indonesia 2 jam pelajaran. Dalam pelaksanaan kegiatannya dilakukan secara murni mata pelajaran yaitu hanya mempelajari standar kompetensi dan kompetensi dasar yang berhubungan dengan mata pelajaran itu. Sesuai dengan tahapan perkembangan anak yang masih melihat segala sesuatu sebagai suatu keutuhan (holistik), pembelajaran yang menyajikan mata pelajaran secara terpisah akan menyebabkan kurang mengembangkan anak untuk berpikir holistik dan membuat kesulitan bagi peserta didik.

Permasalahan tersebut menunjukkan bahwa kesiapan sekolah sebagian besar peserta didik kelas awal sekolah dasar di Indonesia cukup rendah. Sementara itu, hasil penelitian menunjukkan bahwa peserta didik yang telah masuk Taman Kanak-kanak memiliki kesiapan bersekolah lebih baik dibandingkan dengan peserta didik yang tidak mengikuti pendidikan Taman Kanak-kanak. Selain itu, perbedaan pendekatan, model, dan prinsip-prinsip 
pembelajaran antara kelas satu dan dua sekolah dasar dengan pendidikan pra-sekolah dapat juga menyebabkan peserta didik yang telah mengikuti pendidikan pra-sekolah pun dapat saja mengulang kelas atau bahkan putus sekolah.

Berdasarkan pemikiran di atas dan dalam rangka implementasi Standar Isi yang termuat dalam Standar Nasional Pendidikan, maka pembelajaran pada kelas awal sekolah dasar yakni kelas satu, dua, dan tiga lebih sesuai jika dikelola dalam pembelajaran terpadu melalui pendekatan pembelajaran tematik. Untuk memberikan gambaran tentang pembelajaran tematik yang dapat menjadi acuan dan contoh konkret, disiapkan model pelaksanaan pembelajaran tematik untuk SD/MI kelas I hingga kelas III.

Tahun pelajaran 2018/2019 peneliti mendapat beban kerja membimbing guru kelas I sampai kelas III, sebanyak 12 orang guru, terdiri dari 4 orang guru kelas I, 4 orang guru kelas II dan 4 orang guru kelas III. dengan jumlah guru sebanyak 12 orang, sehingga kegiatan supervisi cukup mendapat kendala, karena dalam pelaksanaan supervisi manajerial dan akademik hanya dapat dilaksanakan rata-rata $20 \%$ atau 12 orang guru dalam satu semester. Hal ini terjadi karena kepala sekolah melakukan supervisi akademik langsung pada guru-guru dengan jumlah terbatas yaitu pada guru-guru kelas tertentu menurut skala prioritas. Supervisi akademik selama ini rata-rata 1 orang sampai 3 orang guru setiap minggu dari tiga kelas, pelaksanaan supervisi berkelanjutan sampai tuntas memakan waktu rata-rata tiga sampai empat minggu. Jadi untuk setiap kelas supervisi akademik yang berkelanjutan ratarata memerlukan waktu satu bulan dengan jumlah guru rata-rata 4 orang. Jumlah guru sebanyak 12 orang, selama satu semester yang efektif untuk supervisi akademik dilakukan selama 4 bulan jadi kelas yang disupervisi akademik hanya 1 kelas dengan jumlah guru 4 orang.

Hasil supervisi akademik semester genap tahun pelajaran 2018/2019 antara lain dapat disimpulkan bahwa guru yang memiliki dokumen SNP sangat rendah yaitu standar kompetensi hanya 12,5\%, standar kompetensi lulusan 25\% dan SNP lainnya belum dimiliki. Rancangan pembelajaran yang dibuat oleh guru-guru rata-rata $73 \%$ belum sesuai ramburambu, serta kualitas pembelajaran rata-rata 15\% termasuk katagori baik.dan katagori cukup 85\%. Hal ini disebabkan karena tidak semua guru mendapat kesempatan mengikuti pelatihan/workshop/penataran, begitu pula pemberdayaan Kelompok Kerja Guru (KKG) guru kelas dan implementasi SNP belum dilaksanakan secara optimal.

Berdasarkan supervisi yang dilaksanakan pada tahun pelajaran 2018/2019 semester genap, tidak dapat dilaksanakan pada semua guru-guru di SDN 1 Landasan Ulin Utara, sehingga peningkatan kinerja guru dan peningkatan mutu proses pembelajaran belum merata di SDN 1 Landasan Ulin Utara, jika masalah ini tidak segera diatasi dikhawatirkan guru dalam melaksanakan pembelajaran akan berbuat sekehendak hatinya, sehingga kualitas pembelajaran dan mutu pendidikan akan menurun, untuk mengoptimalkan pelaksanaan supervisi akademik kesemua guru kelas di setiap guru pada semester genap tahun pelajaran 2018/2019 dilakukan workshop terhadap guru untuk meningkatkan keterampilan guru terutama dalam hal pembuatan rencana pelaksanaan pembelajaran tematik.

Berdasarkan uraian di atas untuk rumusan masalahnya adalah Apakah dengan workshop dapat meningkatkan keterampilan guru dalam membuat rencana pelaksanaan 
pembelajaran tematik? Apakah dengan workshop dapat meningkatkan aktivitas guru dalam membuat rencana pelaksanaan pembelajaran tematik?

Rencana pemecahan masalah adalah untuk meningkatkan keterampilan guru dalam membuat rencana pelaksanaan pembelajaran tematik dilakukan kegiatan workshop, untuk mengetahui aktivitas guru dalam membuat rencana pelaksanaan pembelajaran tematik dilakukan dengan observasi kegiatan guru dalam kegiatan workshop.

Tujuan penelitian ini adalah untuk mengetahui Peningkatan keterampilan guru dalam membuat rencana pelaksanaan pembelajaran tematik dengan kegiatan workshop, Peningkatan aktivitas guru dalam membuat rencana pelaksanaan pembelajaran tematik dilakukan observasi kegiatan guru pada saat kegiatan workshop.

Manfaat Penelitian ini antara lain bagi guru, meningkatkan keterampilan guru dalam membuat rancangan pembelajaran yang standar sehingga guru memiliki rasa percaya diri yang tinggi, bagi sekolah memiliki komunitas guru kelas yang profesional, kepala sekolah dapat melaksanakan supervisi akademik secara menyeluruh dan tuntas kepada semua guru disetiap kelas.

\section{METODE}

Penelitian ini menggunakan pendekatan tindakan sekolah yaitu bentuk pembelajaran yang bersifat reflektif untuk memperbaiki kondisi pembelajaran dan meningkatkan kemantapan rasional dari tindakan melaksanakan tugas dengan proses pengkajian berdaur, yaitu merencanakan, melakukan tindakan, mengamati, dan refleksi (Winardi, 2004 : 6).

Berdasarkan pengertian tersebut dapatlah disimpulkan bahwa Penelitian Tindakan Sekolah (PTS) adalah studi sistematis terhadap penyusunan rancangan pembelajaran dan praktek pembelajaran di kelas dengan tujuan untuk memperbaiki dan meningkatkan kualitas proses pembelajaran dan hasil belajar siswa dengan melakukan tindakan tertentu.

Jenis penelitian yang dugunakan dalam penelitian ini adalah Penelitian Tindakan Sekolah dengan bimbingan KKG di sekolah.

Pengertian Penelitian Tindakan Sekolah merupakan suatu pencermatan terhadap penyusunan rancangan pembelajaran dan kegiatan belajar yang berupa tindakan, yang sengaja dimunculkan dan terjadi dalam sebuah kelas secara bersama (Arikunto, 2007:3).

Tahapan pelaksanaan tindakan sekolah dapat digambarkan pada bagan berikut :

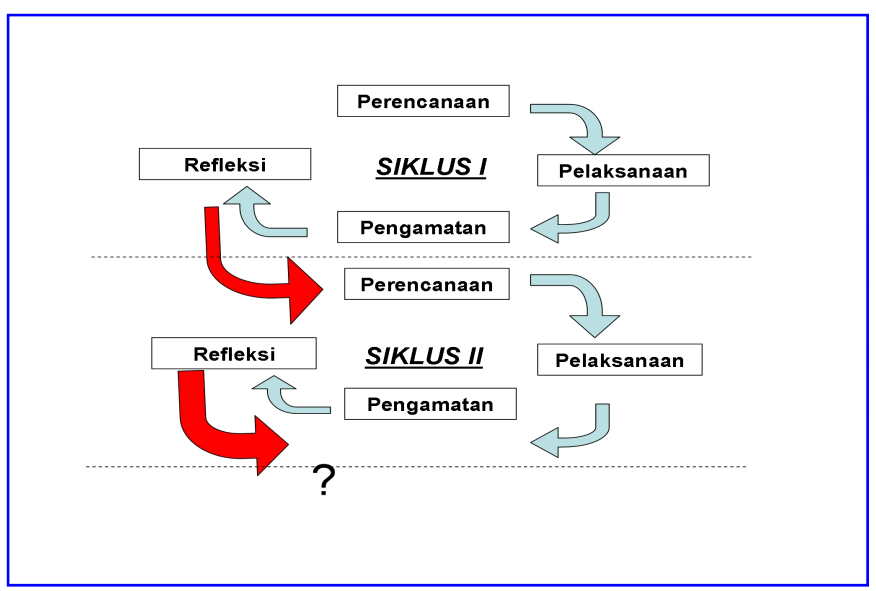

Gambar 1. Langkah-langkah PTS (Direktorat Tendik, 2008) 
Setting Penelitian tindakan sekolah membahas tentang pembinaan kelompok untuk meningkatkan keterampilan guru dalam membuat rencana pelaksanaan pembelajaran tematik pada SDN 1 Landasan Ulin Utara Kecamatan Liang Anggang yang terdiri dari guru kelas I, II, dam III dengan jumlah sebanyak 12 orang.

Untuk menjawab pertanyaan yang dirumuskan dalam penelitian, ada beberapa faktor yang akan di teliti yaitu pelaksanaan workshop mulai dari merumuskan masalah yang akan dibahas, tujuan pembahasan, metode pembahasan, mengerjakan tugas, dan merumuskan kesimpulan; Faktor guru, yaitu mengamati aktivitas guru-guru selama kegiatan workshop, pada saat kegiatan; mengkaji dan mengevaluasi rencana pelaksanaan pembelajaran tematik yang ada (keterampilan guru mengevaluasi rancangan pembelajaran yang ada; merevisi/membuat rencana pelaksanaan pembelajaran tematik (keterampilan guru dalam merivisi/membuat silabus dan RPP, serta merevisi/membuat instrumen observasi/pengamatan); implementasi pembelajaran sesama guru (simulasi); pengamatan antar guru pada saat refleksi dan evaluasi serta menentukan tindak lanjut setelah melakukan workshop.

Skenario tindakan kegiatan awal tindakan penelitian adalah evalusi hasil supervisi guru tahun/semester sebelumnya, tentang supervisi akademik penyusunan rencana pelaksanaan pembelajaran tematik bagi guru kelas I, II, dan III, melalui identifikasi, dan analisis, kemudian mengidentifikasi masalah, selanjutnya dirumuskan menjadi permasalahan penelitian tindakan sekolah yang spesifik.

Pada siklus pertama, tahap perencanaan meliputi menyusun jadwal kegiatan workshop, merumuskan masalah yang akan dibahas tentang RPP, membuat instrumen penilaian hasil produk RPP tematik yang disusun guru, menyusun instrumen penilaian simulasi guru. Tahap implementasi workshop oleh kepala sekolah yaitu peneliti memberikan penambahan wawasan tentang pembuatan RPP tematik, membagi kelompok menjadi 3 kelompok, masingmasing kelompok mengkaji dan mengevaluasi RPP tematik yang dibuat guru secara silang dalam kelompok, merevisi/membuat rancangan pembelajaran melalui workshop. Tahap pengamatan aktivitas guru oleh observer selama pelaksanaan workshop dan produk RPP tematik. Tahap refleksi, dan evaluasi pelaksanaan implementasi workshop.

Pada siklus kedua, tahap perencanaan merumuskan tindakan berdasarkan hasil refleksi dan evaluasi siklus pertama, merencanakan dan menentukan metode pembahasan dalam kegiatan workshop. Tahap implementasi workshop oleh kepala sekolah sekolah yaitu peneliti memberikan penguatan lanjutan tentang pembuatan RPP tematik, membagi kelompok menjadi 3 kelompok dengan mengacak guru, merevisi/membuat rancangan pembelajaran melalui workshop simulasi pembelajaran oleh wakil kelompok secara bergantian. Tahap pengamatan aktivitas guru selama workshop dan penilaian saat simulasi berlangsung serta refleksi dan evaluasi atas tindakan yang telah dilaksanakan di siklus kedua oleh guru-guru di KKG sekolah dan mengambil kesimpulan. Tahap observasi dilaksanakan pada kegiatan kelompok dan penilaian hasil produk RPP yang disusun serta kegiatan simulasi oleh wakil kelompok dengan menggunakan instrumen aktivitas kelompok dan simulasi pembelajaran. Tahap refleksi tindakan hasil observasi dan evaluasi dikumpulkan dan dianalisis pada setiap siklus, dari hasil pengumpulan data pada setiap kegiatan dijadikan acuan untuk merefleksi berdasarkan indikator keberhasilan masing-masing aktivitas. 
Sumber data awal diperoleh dalam penelitian tindakan sekolah ini berasal kegiatan penelitian pada pelatihan penguatan kepala sekolah sekolah dan hasil supervisi akademik pada semester genap tahun pelajaran 2018/2019 dan hasil pengamatan aktivitas guru pada kegiatan KKG tingkat kecamatan. Data hasil penelitian diolah berdasarkan kegiatan workshop di 12 guru SDN 1 Landasan Ulin Utara Kecamatan Liang Anggang.

Jenis data yang dianalisis dalam pelaksanaan penelitian tindakan sekolah ini berupa data kualitatif dan data kuantitatif. Data kualitatif yaitu data-data yang bersifat subyektif dan berupa kata-kata atau kriteria perilaku dalam kegiatan proses pembelajaran yang dilaksanakan. Sedangkan data kuantitatif yaitu data-data yang dapat disajikan dengan menggunakan angka-angka, dan dapat digali dari pengukuran hasil belajar secara tertulis dan bersifat obyektif sebagai nilai pendukung.

Cara pengambilan dan pengumpulan data dapat dilakukan dengan berbagai cara, yaitu data tentang aktivitas guru, dapat dikumpulkan melalui kegiatan workshop, data tentang hasil produk RPP tematik, dapat diperoleh hasil kegiatan workshop.

Analisa data meliputi aktivitas guru, dengan perhitungan persentasi aktivitas guru dalam kegiatan penyusunan rancangan pembelajaran dengan menggunakan rumus sebagai berikut:

$$
\mathrm{P}=\frac{\mathrm{f}}{\mathrm{N}} \times 100 \%
$$

Keterangan:

$\mathrm{P} \quad=$ angka persentasi

$\mathrm{f} \quad=$ frekwensi

$\mathrm{N} \quad=$ number of cases (jumlah frekuensi)

(Sudijono : 2003)

Hasil persentasi dapat dikatagorikan sebagai berikut :

$\begin{array}{ll}81 \%-100 \% & =\text { baik sekali } \\ 61 \%-80 \% & =\text { baik } \\ 41 \%-60 \% & =\text { cukup } \\ 21 \%-40 \% & =\text { kurang } \\ 0 \%-20 \% & =\text { buruk }\end{array}$

Hasil produk rancangan pembelajaran dan simulasi perhitungan hasil penyusunan rancangan pembelajaran dengan menggunakan rumus sebagai berikut:

$$
\mathrm{P}=\frac{\mathrm{jr}}{\mathrm{Ni}} \times 100
$$

Keterangan:

$\mathrm{P} \quad=$ angka persentasi

jr $\quad=$ Jumlah nilai riil

$\mathrm{Ni} \quad=$ Jumlah nilai ideal 
Hasil persentasi dapat dikatagorikan sebagai berikut:

$\begin{array}{ll}81 \text { s.d. } 100 & =\text { sangat baik } \\ 61 \text { s.d. } 80 & =\text { baik } \\ 41 \text { s.d. } 60 & =\text { cukup } \\ 21 \text { s.d. } 40 & =\text { kurang baik } \\ \leq 20 & =\text { tidak ada }\end{array}$

Indikator keberhasilan penyusunan rancangan pembelajaran dan proses belajar mengajar menurut Fathurrohman, et. al. (2007) apabila 85\% dari jumlah guru mencapai taraf keberhasilan yang optimal (mencapai $75 \%$ penguasaan materi).

Proses pembimbingan dianggap berhasil apabila keterampilan guru dalam membuat rancangan pembelajaran mencapai kualifikasi baik. Adapun indikator keberhasilan dalam aspek aktivitas guru dalam membuat rancangan pembelajaran adalah apabila $75 \%$ dari jumlah guru yang mengikuti proses pembimbingan dapat menguasai minimal $80 \%$ dari materi bimbingan (Djamarah, Zain, 2006:73)

Ukuran yang dijadikan keberhasilan dalam penelitian tindakan sekolah di SDN 1 Landasan Ulin Utara Kecamatan Liang Anggang adalah apabila tingkat penguasaan individu mencapai $\geq 75 \%$ dan ketuntasan secara kelompok adalah $\geq 80 \%$.

\section{HASIL PENELITIAN}

\section{Pemaparan Data Siklus ke I}

Penelitian pendahuluan ini dilakukan untuk merumuskan masalah-masalah yang terjadi pada subyek penelitian. Hal ini dilakukan pada saat melakukan supervisi akademik semester genap tahun 2018/2019 pada guru SDN 1 Landasan Ulin Utara Kecamatan Liang Anggang, dengan temuan melalui indentifikasi permasalahan proses pembelajaran yang dihadapi oleh guru, observasi rancangan pembelajaran dan diskusi dengan guru-guru dari beberapa guru kelas 1,2, dan 3 .

Hasil observasi pengumpulan data dan studi dokumen hasil supervisi akademik telah ditemukan yaitu silabus umumnya masih adopsi dari Badan Standar Nasional Pendidikan (BSNP) atau yang lainnya; Rencana Pelaksanaan Pembelajaran (RPP) tematik umumnya belum lengkap sesuai ketentuan, antara lain tujuan pembelajaran tidak lengkap, instrumen soal, kunci/kriteria jawaban, pedoman penilaian dan atau tidak sesuai dengan silabus; Proses pembelajaran umumnya sudah berpusat pada siswa, tetapi tidak menggunakan rancangan pembelajaran yang sudah dibuat, sehingga proses pembelajaran tidak sesuai dengan yang direncanakan; Rancangan pembelajaran (Silabus dan RPP) umumnya belum berfungsi/belum digunakan sebagai acuan proses pembelajaran; Umumnya semua guru memiliki permasalah dalam proses pembelajaran yaitu siswa kurang aktif, kurang berani mengemukakan pendapat; Pelaksanaan supervisi akademik yang dilakukan secara langsung yaitu antara kepala sekolah dan guru hasilnya hanya beberapa guru saja karena jumlah guru disekolah banyak serta jumlah guru sebanyak 13 sekolah namun yang diteliti hanya 7 sekolah.

Hasil diskusi/perenungan dengan guru-guru dari beberapa guru kelas di sekolah adalah silabus dari BSNP atau dari sumber yang lainnya dianggap sudah benar, belum dikaji, dan dievaluasi; RPP hasil adopsi dianggap sudah benar, dan belum dikaji dan evaluasi; 
Rancangan pembelajaran setiap semester/tahun tidak berkelanjutan, karena belum dievaluasi, direvisi atau membuat yang baru sesuai dengan potensi siswa dan sekolah; Pelaksanaan supervisi akademik perlu menyeluruh pada semua guru secara berkelanjutan dan tuntas pada semua SDN 1 Landasan Ulin Utara.

Berdasarkan data tersebut maka alternatif pemecahan masalah antara lain melalui supervisi akademik yang efektif dan fokus pada rencana pelaksanaan pembelajaran guru melalui workshop di KKG sekolah. Rencana tindakan pada siklus I tergambar sebagaimana tabel 1 berikut ini:

Tabel 1. Rencana Tindakan Siklus I

\begin{tabular}{|c|c|}
\hline Tindakan & Manfaat \\
\hline $\begin{array}{l}\text { 1. Kepala sekolah sekolah mengumpulkan } \\
\text { semua guru-guru di guruuntuk } \\
\text { menyampaikan: } \\
\text { - hasil supervisi akademik tentang silabus } \\
\text { dan RPP tematik. } \\
\text { - program supervisi akademik yang } \\
\text { berbasis KKG sekolah/komunitas guru } \\
\text { di sekolah melalui workshop. }\end{array}$ & $\begin{array}{ll}\text { a. } & \text { Guru-guru memperoleh gambaran } \\
\text { kelebihan dan kekurangannya serta } \\
\text { manfaat supervisi akademik. } \\
\text { b. } \\
\text { Membantu guru-guru melalui } \\
\text { pemberdayaan KKG untuk } \\
\text { membangun komunitas } \\
\text { pembelajaran profesional. } \\
\text { c. Memudahkan guru-guru dalam } \\
\text { membuat silabus dan RPP secara } \\
\text { mandiri. }\end{array}$ \\
\hline $\begin{array}{l}\text { 2. Kepala sekolah-sekolah memberikan } \\
\text { bimbingan mengevaluasi, merevisi silabus } \\
\text { dan RPP sudah ada di setiap KKG di } \\
\text { sekolah. } \\
\text { 3. Kepala sekolah sekolah mengevaluasi } \\
\text { silabus dan RPP hasil kegiatan KKG } \\
\text { sekolah sesuai instrumen yang sudah } \\
\text { digunakan oleh guru-guru sebelumnya. }\end{array}$ & $\begin{array}{l}\text { d. Memudahkan guru dalam membuat } \\
\text { silabus dan RPP secara efektif dan } \\
\text { berkelanjutan, sehingga tidak } \\
\text { menjadi beban dengan cara } \\
\text { mengkaji, mengevaluasi rancangan } \\
\text { pembelajaran yang sudah ada, } \\
\text { kemudian merevisi/membuat } \\
\text { rancangan pembelajaran yang } \\
\text { lengkap sesuai rambu-rambu melalui } \\
\text { workshop. }\end{array}$ \\
\hline $\begin{array}{l}\text { 4.Kepala sekolah sekolah bersama-sama } \\
\text { melakukan refleksi, dan evaluasi bersama } \\
\text { semua guru kelas rendah untuk } \\
\text { menentukan program tindak lanjut. }\end{array}$ & 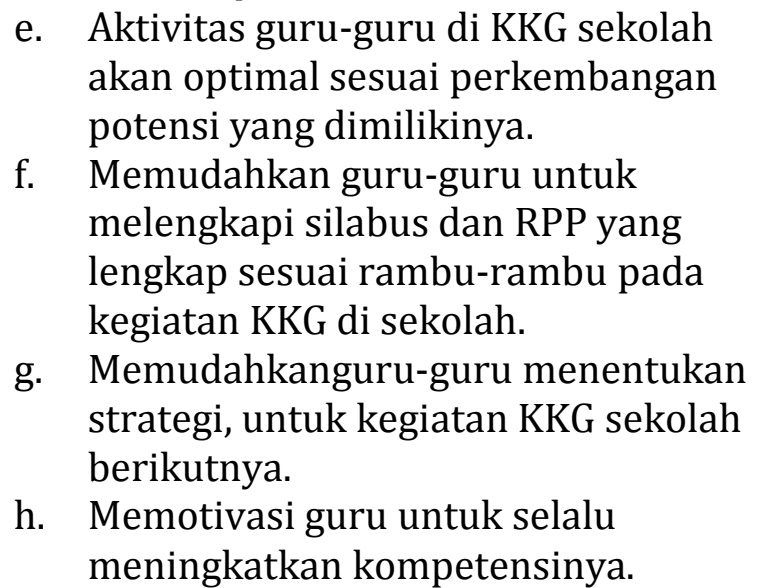 \\
\hline
\end{tabular}


Rencana tindakan pada siklus I tergambar sebagaimana tabel 2 berikut ini:

Tabel 2. Rencana Tindakan Siklus II

\begin{tabular}{|c|c|}
\hline Tindakan & Manfaat \\
\hline $\begin{array}{l}\text { 1. Kepala sekolah sekolah mengumpulkan } \\
\text { perwakilan guru dari KKG sebagai guru } \\
\text { pembimbing/pemandu kemudian kepala } \\
\text { sekolah memberikan permasalahan } \\
\text { pembelajaran guru-guru dan kepala } \\
\text { sekolah memberikan contoh rancangan } \\
\text { pembelajaran yang lengkap sesuai } \\
\text { rambu-rambu untuk semua guru-guru di } \\
\text { KKG sekolah. }\end{array}$ & $\begin{array}{l}\text { Melalui bimbingan guru pemandu di KKG } \\
\text { sekolah, guru-guru mengidentifikasi } \\
\text { masalah pembelajaran, kemudian } \\
\text { membuat rancangan pembelajaran yang } \\
\text { lengkap sesuai rambu-rambu untuk } \\
\text { memecahkan salah satu masalah } \\
\text { pembelajaran. }\end{array}$ \\
\hline $\begin{array}{l}\text { 2. Kepala sekolah sekolah mengevaluasi } \\
\text { rancangan pembelajaran dari semua guru } \\
\text { kemudian mengumpulkan semua guru } \\
\text { kelas rendah untuk melakukan refleksi. }\end{array}$ & $\begin{array}{l}\text { Guru-guru di KKG sekolah melakukan } \\
\text { refleksi, dan evaluasi. } \\
\text { Memotivasi guru-guru membuat } \\
\text { rancangan yang lengkap, efektif dan } \\
\text { berkelanjutan serta sesuai rambu-rambu. }\end{array}$ \\
\hline
\end{tabular}

Hasil observasi terhadap aktivitas guru di KKG di sekolah selama workshop adalah sebagai berikut :

Tabel 3. Hasil penilaian aktivitas guru dalam kelompok siklus I

\begin{tabular}{|c|c|c|c|c|c|}
\hline \multirow{2}{*}{ No. } & \multirow{2}{*}{ Aspek yang diobservasi } & \multicolumn{4}{|c|}{ Skor Nilai dan Kelompok } \\
\hline & & 1 & 2 & 3 & 4 \\
\hline 1 & Kerja sama & 4 & 4 & 4 & 3 \\
\hline 2 & Mengemukakan gagasan/ide & 3 & 3 & 4 & 2 \\
\hline 3 & Mengajukan pertanyaan & 2 & 3 & 2 & 2 \\
\hline 4 & Mengkaji rancangan pembelajaran & 3 & 3 & 3 & 3 \\
\hline 5 & Mengambil keputusan & 2 & 2 & 3 & 3 \\
\hline \multirow[t]{4}{*}{6} & Memecahkan masalah & 3 & 3 & 3 & 3 \\
\hline & Jumlah & 17 & 18 & 19 & 16 \\
\hline & Persentase (\%) & 70,83 & 75,00 & 79,16 & 66,67 \\
\hline & Rata-Rata & \multicolumn{4}{|c|}{$72,92 \%$} \\
\hline
\end{tabular}

Hasil penilaian skala likert guru-guru di KKG di sekolah selama workshop sebagai berikut: 
Tabel 4. Hasil penilaian sikap dan minat guru-guru pada siklus I

\begin{tabular}{|c|c|c|c|c|c|}
\hline \multirow{2}{*}{ No. } & \multirow{2}{*}{ Aspek } & \multicolumn{4}{|c|}{ Skor Nilai dan Kelompok } \\
\hline & & 1 & 2 & 3 & 4 \\
\hline 1 & Sangat bermanfaat & 3 & 4 & 4 & 3 \\
\hline 2 & Sangat menyenangkan & 3 & 3 & 3 & 3 \\
\hline 3 & Menambah wawasan & 3 & 3 & 3 & 2 \\
\hline 4 & Sangat termotivasi & 3 & 3 & 3 & 2 \\
\hline 5 & Mudah dipahami & 2 & 3 & 3 & 2 \\
\hline 6 & Semangat kebersamaan & 3 & 4 & 3 & 3 \\
\hline 7 & Menambah percaya diri & 3 & 3 & 3 & 2 \\
\hline 8 & Suasana saling menghargai & 2 & 3 & 3 & 3 \\
\hline 9 & Saling tukar informasi & 2 & 3 & 3 & 2 \\
\hline \multirow[t]{4}{*}{10} & $\begin{array}{l}\text { Sangat tertarik membuat } \\
\text { rancangan pembelajaran }\end{array}$ & 3 & 3 & 3 & 3 \\
\hline & Jumlah & 27 & 32 & 31 & 25 \\
\hline & Persentasi (\%) & 67,50 & 80,00 & 77,50 & 62,50 \\
\hline & Rata-Rata & \multicolumn{4}{|c|}{$71,88 \%$} \\
\hline
\end{tabular}

Hasil kegiatan KKG sekolah adalah silabus dan RPP dari 24 orang guru, kemudian dievaluasi dengan hasil sebagai berikut:

Tabel 5. Hasil evaluasi silabus dan RPP pada siklus I

\begin{tabular}{clrrrr}
\hline \multirow{2}{*}{ No. Aspek yang diamati } & \multicolumn{4}{c}{ Skor / Kelompok } \\
& \multicolumn{1}{c}{ SILABUS : } & 1 & 2 & 3 & 4 \\
\hline & Identitas mata pelajaran atau tema pelajaran & 4 & 4 & 4 & 4 \\
1 & Standar kompetensi & 4 & 4 & 4 & 4 \\
2 & Kompetensi dasar & 4 & 4 & 4 & 4 \\
3 & Materi pembelajaran & 4 & 4 & 4 & 4 \\
4 & Kegiatan pembelajaran & 4 & 3 & 4 & 3 \\
5 & Indikator pencapaian kompetensi & 3 & 3 & 4 & 3 \\
6 & Penilaian & 3 & 3 & 3 & 3 \\
7 & Alokasi waktu & 4 & 4 & 3 & 4 \\
8 & Sumber belajar & 3 & 3 & 4 & 3 \\
9 & RENCANA PELAKSANAAN PEMBELAJARAN: & & & & \\
10 & Identitas mata pelajaran & 4 & 4 & 4 & 4 \\
11 & Standar kompetensi & 4 & 4 & 4 & 4 \\
12 & Kompetensi Dasar & 4 & 4 & 4 & 4 \\
13 & Indikator pencapaian kompetensi & 3 & 3 & 4 & 3 \\
14 & Tujuan Pembelajaran & 4 & 4 & 4 & 4 \\
15 & Materi Ajar & 4 & 4 & 4 & 4 \\
16 & Metode Pembelajaran/Pendekatan & 3 & 3 & 3 & 3 \\
\hline
\end{tabular}




\begin{tabular}{|c|c|c|c|c|c|}
\hline 17 & Alokasi Waktu & 4 & 4 & 4 & 4 \\
\hline 18 & Sumber Belajar & 3 & 3 & 3 & 3 \\
\hline & Kegiatan Pembelajaran & & & & \\
\hline 19 & $\begin{array}{l}\text { Pendahuluan } \\
\text { Inti }\end{array}$ & 3 & 3 & 4 & 3 \\
\hline & Penutup & & & & \\
\hline 20 & Penilaian Hasil Belajar & 4 & 4 & 4 & 4 \\
\hline & JUMLAH & 73 & 72 & 76 & 72 \\
\hline & RATA-RATA & \multicolumn{4}{|c|}{73,25} \\
\hline
\end{tabular}

\section{Pemaparan Data Siklus ke II}

Berdasarkan permasalahan di atas yang muncul pada siklus I, maka rancangan tindakan pada siklus II seperti ditunjukkan pada tabel 6 .

Tabel 6. Rancangan tindakan

\begin{tabular}{cc} 
Tindakan & Manfaat \\
\hline 1. Kepala
\end{tabular}

1. Kepala sekolah mengumpulkan perwakilan guru dari KKG sebagai guru pembimbing/pemandu (guru yang terbaik membuat rancangan pembelajaran yang lengkap sesuai rambu-rambu).

2. Kepala sekolah sekolah memberikan contoh instrumen obervasi pembelajaran kepada guru perwakilan/pemandu dari KKG sekolah untuk observasi proses pembelajaran dan laporan hasil refleksi.

3. Kepala sekolah sekolah mengumpulkan semua guru mata pelajaran untuk melakukan refleksi yang disampaikan oleh guru pemandu dari setiap KKG sekolah. Kepala sekolah sekolah bertindak sebagai fasilitator, dan motivator.
Melalui bimbingan guru pemandu di KKG sekolah, guru-guru mengidentifikasi masalah pembelajaran, kemudian membuat rancangan pembelajaran yang lengkap sesuai rambu-rambu untuk memecahkan salah satu masalah pembelajaran.

Melalui bimbingan guru pemandu setiap KKG sekolah mengkaji, merevisi/membuat instrumen observasi pembelajaran.

Memotivasi guru agar dapat mengambil keputusan dan memecahkan masalah pembelajaran bebas mengemukakan pendapat/ide/gagasan sesuai potensinya.

Hasil observasi terhadap aktivitas guru di KKG di sekolah selama workshop adalah sebagai berikut :

Tabel 7. Hasil penilaian aktivitas guru dalam kelompok siklus II 


\begin{tabular}{clcccc}
\hline \multirow{2}{*}{ No } & \multicolumn{2}{c}{ Aspek yang diobservasi } & \multicolumn{4}{c}{ Skor Nilai dan Kelompok } \\
& & 1 & 2 & 3 & 4 \\
\hline 1 & Kerja sama & 4 & 4 & 4 & 4 \\
2 & Mengemukakan gagasan/ide & 4 & 4 & 4 & 4 \\
3 & Mengajukan pertanyaan & 3 & 3 & 3 & 3 \\
4 & Mengkaji rancangan pembelajaran & 4 & 4 & 4 & 3 \\
5 & Mengambil keputusan & 3 & 3 & 3 & 3 \\
6 & Memecahkan masalah & 3 & 4 & 4 & 3 \\
Jumlah & 21 & 22 & 22 & 20 \\
Perentase (\%) & 87,50 & 91,67 & 91,67 & 83,33 \\
Rata-rata & $88,54 \%$ & & & \\
\hline
\end{tabular}

Hasil penilaian skala likert guru-guru di KKG di sekolah selama kegiatan workshop sesuai tabel 8 adalah sebagai berikut:

Tabel 8. Hasil penilaian sikap dan minat guru-guru pada siklus II

\begin{tabular}{|c|c|c|c|c|c|}
\hline \multirow{2}{*}{ No } & \multirow{2}{*}{ Aspek } & \multicolumn{4}{|c|}{ Skor Nilai dan Kelompok } \\
\hline & & 1 & 2 & 3 & 4 \\
\hline 1 & Sangat bermanfaat & 4 & 4 & 4 & 4 \\
\hline 2 & Sangat menyenangkan & 4 & 4 & 4 & 4 \\
\hline 3 & Menambah wawasan & 4 & 4 & 4 & 3 \\
\hline 4 & Sangat termotivasi & 3 & 4 & 3 & 3 \\
\hline 5 & Mudah dipahami & 3 & 4 & 3 & 3 \\
\hline 6 & Semangat kebersamaan & 3 & 4 & 4 & 3 \\
\hline 7 & Menambah percaya diri & 3 & 4 & 4 & 3 \\
\hline 8 & Suasana saling menghargai & 3 & 3 & 4 & 3 \\
\hline 9 & Saling tukar informasi & 2 & 3 & 3 & 3 \\
\hline 10 & $\begin{array}{l}\text { Sangat tertarik } \begin{array}{l}\text { membuat } \\
\text { rancangan }\end{array} \\
\text { pembelajaran }\end{array}$ & 4 & 3 & 3 & 3 \\
\hline \multicolumn{2}{|c|}{ Jumlah } & 33 & 37 & 36 & 32 \\
\hline \multicolumn{2}{|c|}{ Persentase (\%) } & 82,50 & 92,50 & 90,00 & 80,00 \\
\hline \multicolumn{2}{|c|}{ Rata-Rata } & \multicolumn{4}{|c|}{$86,25 \%$} \\
\hline
\end{tabular}

Hasil kegiatan KKG sekolah adalah rancangan pembelajaran dari guru-guru mata pelajaran, kemudian dievaluasi dengan hasil sebagai berikut:

Tabel 9. Hasil evaluasi silabus dan RPP pada siklus II 


\begin{tabular}{|c|c|c|c|c|c|}
\hline \multirow{2}{*}{ No } & \multirow{2}{*}{ Aspek yang diamati } & \multicolumn{4}{|c|}{ Skor / Kelompok } \\
\hline & & 1 & 2 & 3 & 4 \\
\hline \multicolumn{6}{|c|}{ SILABUS : } \\
\hline 1 & Identitas mata pelajaran atau tema pelajaran & 5 & 5 & 5 & 5 \\
\hline 2 & Standar kompetensi & 4 & 4 & 4 & 4 \\
\hline 3 & Kompetensi dasar & 5 & 5 & 4 & 4 \\
\hline 4 & Materi pembelajaran & 5 & 5 & 5 & 5 \\
\hline 5 & Kegiatan pembelajaran & 4 & 5 & 5 & 5 \\
\hline 6 & Indikator pencapaian kompetensi & 4 & 4 & 4 & 4 \\
\hline 7 & Penilaian & 4 & 4 & 5 & 4 \\
\hline 8 & Alokasi waktu & 5 & 5 & 5 & 5 \\
\hline 9 & Sumber belajar & 4 & 5 & 5 & 4 \\
\hline \multicolumn{6}{|c|}{ RENCANA PELAKSANAAN PEMBELAJARAN: } \\
\hline 10 & Identitas mata pelajaran & 5 & 5 & 5 & 5 \\
\hline 11 & Standar kompetensi & 4 & 4 & 4 & 4 \\
\hline 12 & Kompetensi Dasar & 5 & 5 & 5 & 5 \\
\hline 13 & Indikator pencapaian kompetensi & 4 & 5 & 4 & 4 \\
\hline 14 & Tujuan Pembelajaran & 5 & 5 & 5 & 5 \\
\hline 15 & Materi Ajar & 4 & 5 & 5 & 4 \\
\hline 16 & Metode Pembelajaran/Pendekatan & 4 & 4 & 5 & 4 \\
\hline 17 & Alokasi Waktu & 5 & 5 & 5 & 5 \\
\hline 18 & Sumber Belajar & 5 & 4 & 5 & 4 \\
\hline 19 & Kegiatan Pembelajaran Pendahuluan Inti Penutup & 5 & 4 & 4 & 4 \\
\hline \multirow[t]{3}{*}{20} & Penilaian Hasil Belajar & 4 & 5 & 5 & 5 \\
\hline & JUMLAH & 90 & 93 & 94 & 89 \\
\hline & RATA-RATA & \multicolumn{4}{|c|}{91,50} \\
\hline
\end{tabular}

\section{Perbandingan Data Setiap Siklus}

Tindakan-tindakan yang telah dilakukan oleh kepala sekolah selaku peneliti dan guru pada setiap siklus sesuai tabel 10 telah menghasilkan beberapa hal yaitu:

Tabel 10. Hasil refleksi dari siklus I dan II 


\begin{tabular}{|c|c|c|c|}
\hline & Tindakan & Tujuan & Hasil \\
\hline 1. & $\begin{array}{l}\text { Kepala sekolah sekolah } \\
\text { mengumpulkan semua } \\
\text { guru-guru di guruuntuk } \\
\text { menyampaikan: } \\
\text { - Hasil supervisi } \\
\text { akademik tentang } \\
\text { rancangan } \\
\text { pembelajaran berupa } \\
\text { silabus dan RPP yang } \\
\text { telah dibuat guru. } \\
\text { - Program supervisi } \\
\text { akademik yang berbasis } \\
\text { KKG sekolah melalui } \\
\text { workshop. }\end{array}$ & $\begin{array}{l}\text { - Agar guru-guru } \\
\text { memperoleh gambaran } \\
\text { kelebihan dan } \\
\text { kekurangannya serta } \\
\text { manfaat kegiatan } \\
\text { workshop dengan } \\
\text { supervisi akademik. } \\
\text { - Untuk membantu guru- } \\
\text { guru melalui } \\
\text { pemberdayaan KKG } \\
\text { sekolah untuk } \\
\text { membangun komunitas } \\
\text { pembelajaran profesional. } \\
\text { - Untuk sosialisasi SNP dan } \\
\text { memudahkan guru-guru } \\
\text { dalam membuat } \\
\text { rancangan pembelajaran } \\
\text { yang lengkap. }\end{array}$ & $\begin{array}{l}\text { - Guru aktif mengkaji } \\
\text { rancangan pembelajaran } \\
\text { yang telah dievaluasi. } \\
\text { - Optimalisasi kegiatan } \\
\text { KKG sekolah. } \\
\text { - } \text { Guru memiliki dokumen } \\
\text { SNP dan rancangan } \\
\text { pembelajaran sesuai SNP. }\end{array}$ \\
\hline 2. & $\begin{array}{l}\text { Kepala sekolah sekolah } \\
\text { memberikan bimbingan } \\
\text { mengevaluasi, merevisi } \\
\text { rancangan pembelajaran } \\
\text { yang sudah ada, atau } \\
\text { membuat membuat } \\
\text { rancangan pembelajaran } \\
\text { dilakukan oleh semua } \\
\text { guru di setiap KKG di } \\
\text { sekolah. }\end{array}$ & $\begin{array}{l}\text { - Untuk memudahkan guru } \\
\text { dalam membuat } \\
\text { rancangan pembelajaran } \\
\text { efektif dan berkelanjutan, } \\
\text { sehingga tidak menjadi } \\
\text { beban dengan cara } \\
\text { mengkaji, mengevaluasi } \\
\text { rancangan pembelajaran } \\
\text { yang sudah ada,kemudian } \\
\text { merevisi/membuat } \\
\text { rancangan pembelajaran } \\
\text { yang lengkap sesuai } \\
\text { rambu-rambu melalui } \\
\text { workshop. } \\
\text { - agar aktivitas guru-guru } \\
\text { di KKG sekolah akan } \\
\text { optimal sesuai } \\
\text { perkembangan potensi } \\
\text { yang dimilikinya. }\end{array}$ & $\begin{array}{l}\text { - Guru-guru aktif mengkaji, } \\
\text { merevisi/membuat } \\
\text { rancangan pembelajaran } \\
\text { (aktif bekerja sama, } \\
\text { mengambil keputusan, } \\
\text { mengemukakan ide, } \\
\text { memecahkan masalah, } \\
\text { mengajukan pertanyaan). }\end{array}$ \\
\hline 3. & $\begin{array}{l}\text { Kepala sekolah sekolah } \\
\text { mengevaluasi rancangan } \\
\text { pembelajaran hasil } \\
\text { kegiatan KKG sekolah } \\
\text { sesuai instrumen evaluasi } \\
\text { rancangan yang sudah } \\
\text { digunakan oleh guru-guru } \\
\text { sebelumnya. }\end{array}$ & $\begin{array}{l}\text { - Guru-guru mengetahui } \\
\text { kekurangan rancangan } \\
\text { pembelajaran dan untuk } \\
\text { melengkapi rancangan } \\
\text { pembelajaran yang delum } \\
\text { lengkap sesuai rambu- } \\
\text { rambu pada kegiatan KKG } \\
\text { di sekolah. } \\
\text { - Untuk memudahkan }\end{array}$ & $\begin{array}{l}\text { - Rancangan pembelajaran } \\
\text { yang lengkap sesuai } \\
\text { rambu-rambu. } \\
\text { - Terdapat guru-guru yang } \\
\text { membuat rancangan } \\
\text { pembelajarannya lengkap } \\
\text { dan benar. } \\
\text { - Sikap dan minat guru } \\
\text { sangat baik. }\end{array}$ \\
\hline 4. & $\begin{array}{l}\text { Kepala sek } \\
\text { bersama m }\end{array}$ & $\begin{array}{l}\text { guru-guru menentukan } \\
\text { strategi, kegiatan KKG }\end{array}$ & \\
\hline
\end{tabular}




\begin{tabular}{|c|c|c|c|}
\hline & $\begin{array}{l}\text { refleksi, dan evaluasi } \\
\text { bersama semua guru } \\
\text { kelas, untuk menentukan } \\
\text { program tindak lanjut, } \\
\text { kemudian } \\
\text { merekomdasikan guru } \\
\text { pemandu di KKG sekolah }\end{array}$ & $\begin{array}{l}\text { sekolah berikutnya. } \\
\text { - Untuk memotivasi guru } \\
\text { untuk selalu } \\
\text { meningkatkan } \\
\text { kompetensinya. }\end{array}$ & \\
\hline 5. & $\begin{array}{l}\text { Kepala sekolah } \\
\text { mengumpulkan } \\
\text { perwakilan guru dari KKG } \\
\text { sebagai guru } \\
\text { pembimbing/pemandu } \\
\text { (guru yang terbaik } \\
\text { membuat rancangan } \\
\text { pembelajaran yang } \\
\text { lengkap sesuai rambu- } \\
\text { rambu). }\end{array}$ & $\begin{array}{l}\text { - Untuk memberdayakan } \\
\text { potensi guru melalui } \\
\text { bimbingan oleh guru } \\
\text { pemandu di KKG sekolah. } \\
\text { - Untuk memudahkan } \\
\text { membuat rancangan } \\
\text { pembelajaran yang } \\
\text { lengkap dan benar. }\end{array}$ & $\begin{array}{l}\text { - Mulai terbentuk } \\
\text { komunitas pembelajaran } \\
\text { yang profesional dan } \\
\text { memiliki guru pemandu } \\
\text { di setiap KKG sekolah. } \\
\text { - Setiap guru mempunyai } \\
\text { rancangan pembelajaran } \\
\text { yang lengkap dan benar } \\
\text { minimal satu kompetensi } \\
\text { dasar. }\end{array}$ \\
\hline 6. & $\begin{array}{l}\text { Kepala sekolah } \\
\text { memberikan contoh } \\
\text { rancangan pembelajaran } \\
\text { yang lengkap sesuai } \\
\text { rambu-rambu, model- } \\
\text { model pembelajaran yang } \\
\text { efektif }\end{array}$ & & \\
\hline 7. & $\begin{array}{l}\text { Kepala sekolah sekolah } \\
\text { memberikan contoh } \\
\text { instrumen obervasi } \\
\text { pembelajaran kepada guru } \\
\text { perwakilan/pemandu dari } \\
\text { KKG sekolah untuk } \\
\text { observasi proses } \\
\text { pembelajaran dan laporan } \\
\text { hasil refleksi. }\end{array}$ & $\begin{array}{l}\text { - Untuk memotivasi guru } \\
\text { setiap KKG sekolah } \\
\text { mengkaji, } \\
\text { merevisi/membuat } \\
\text { instrumen observasi } \\
\text { pembelajaran. } \\
\text { - Agar setiap KKG sekolah } \\
\text { melaksanakan } \\
\text { pembelajaran yang } \\
\text { mendidik di } \\
\text { kelas/laboratorium/ } \\
\text { diluar kelas. }\end{array}$ & $\begin{array}{l}\text { - Instrumen observasi } \\
\text { aktivitas untuk guru dan } \\
\text { siswa selama proses } \\
\text { pembelajaran. }\end{array}$ \\
\hline 8. & $\begin{array}{l}\text { Kepala sekolah sekolah } \\
\text { mengevaluasi rancangan } \\
\text { pembelajaran dari semua } \\
\text { guru kelas }\end{array}$ & $\begin{array}{l}\text { - } \text { Agar guru-guru di KKG } \\
\text { sekolah melakukan } \\
\text { refleksi, dan evaluasi. } \\
\text { - Untuk memotivasii guru- } \\
\text { guru membuat rancangan } \\
\text { yang lengkap, efektif, } \\
\text { berkelanjutan, dan sesuai } \\
\text { rambu-rambu. } \\
\text { - Untuk memotivasi guru } \\
\text { agar dapat mengambil } \\
\text { keputusan dan } \\
\text { memecahkan masalah } \\
\text { pembelajaran. }\end{array}$ & $\begin{array}{l}\text { - Kesepakatan dan } \\
\text { komitmen untuk } \\
\text { perbaikan rancangan } \\
\text { pembelajaran dan proses } \\
\text { pembelajaran berikutnya } \\
\text { (berkelanjutan). } \\
\text { - Rancangan pembelajaran } \\
\text { yang lengkap dan benar. } \\
\text { - Guru dapat mengambil } \\
\text { keputusan dalam } \\
\text { memecahkan masalah. }\end{array}$ \\
\hline
\end{tabular}




\begin{tabular}{lll}
\hline 9. & Kepala sekolah sekolah & - \\
mengumpulkan semua & mengemukakan & Komitmen secara \\
guru mata pelajaran untuk & pendapat/ide/gagasan & sukarela untuk selalu \\
melakukan refleksi yang & sesuai potensinya, dan & kompetensi melalui \\
disampaikan oleh guru & dapat memecahkan & inovasi. \\
pemandu dari setiap KKG & masalah serta mengambil & - Sikap dan minat guru \\
sekolah. Kepala sekolah & keputusan, sehingga & sangat baik \\
sekolah bertindak sebagai & kompetensi guru-guru & \\
fasilitator, dan motivator & tumbuh. & \\
\hline
\end{tabular}

\section{PEMBAHASAN}

Analisis aktivitas guru dalam kegiatan workshop pada kegiatan kelompok dengan nilai sebagai berikut; kelompok 1 memperoleh nilai 70,83\% kategori baik, kelompok 2 adalah 75,00\% kategori baik, kelompok 3 adalah 79,16\% kategori baik dan kelompok 4 adalah $66,67 \%$. Pada kegiatan ini rata-rata aktivitas guru adalah 72,92\% dengan kategori baik.

Sikap dan minat guru dalam kegiatan workshop memperoleh nilai yaitu kelompok 1 adalah 67,50\% kategori baik, kelompok 2 adalah 80,00\% kategori baik, kelompok 3 adalah 77,50\% kategori baik dan kelompok 4 adalah 62,50\% kategori baik, skor perolehan rata-rata pada penilaian sikap dan minat guru adalah 71,88\% kategori baik.

Penilaian hasil produk workshop berupa silabus dan RPP tematik adalah; kelompok 1 adalah 73 kategori baik, kelompok 2 adalah 72 kategori baik, kelompok 3 adalah 76 kategori baik dan kelompok 4 adalah 72 kategori baik, skor rata-rata hasil pelaksanaan workshop adalah 73,25.

Kegiatan workshop pada siklus 1 dapat disimpulkan bahwa aktivitas guru, sikap dan minat guru, hasil produk pelaksanaan workshop berupa silabus dan RPP adalah termasuk kategori baik, namun perlu ditingkatkan agar lebih baik lagi pada kegiatan workshop siklus II.

Berdasarkan analisis hasil penelitian pada siklus I yang telah diuraikan di atas, masalah-masalah pada siklus II dapat diuraikan yaitu bagaimana cara menentukan strategi workshop di KKG sekolah untuk mengaktifkan guru dalam mengkaji rancangan pembelajaran, mengambil keputusan dan pemecahan masalah? mudah dipahami dan meningkatkan rasa percaya diri guru-guru? Cara meningkatkan keterampilan guru dalam merevisi/membuat rancangan pembelajaran yang sesuai rambu-rambu, lengkap dan benar?

Analisis aktivitas guru dalam kegiatan workshop pada kegiatan kelompok dengan nilai sebagai berikut; kelompok 1 memperoleh nilai 87,50\% kategori baik sekali, kelompok 2 adalah 91,67\% kategori baik sekali, kelompok 3 adalah 91,67\% kategori baik sekali dan kelompok 4 adalah 83,33\% kategori baik sekali. Pada kegiatan ini rata-rata aktivitas guru adalah $88,54 \%$ dengan kategori baik sekali.

Sikap dan minat guru dalam kegiatan workshop memperoleh nilai yaitu kelompok 1 adalah 82,50\% kategori baik sekali, kelompok 2 adalah 92,50\% kategori baik sekali, kelompok 3 adalah 90,00\% kategori baik sekali dan kelompok 4 adalah 80,00\% kategori baik sekali, Skor perolehan rata-rata pada penilaian sikap dan minat guru adalah $86,25 \%$ kategori baik sekali.

Penilaian hasil produk workshop berupa silabus dan RPP tematik adalah; kelompok 1 adalah 90 kategori baik sekali, kelompok 2 adalah 93 kategori baik sekali, kelompok 3 adalah 
94 kategori baik sekali dan kelompok 4 adalah 89 kategori baik sekali, skor rata-rata hasil pelaksanaan workshop adalah 91,50 dengan kategori baik sekali.

Berdasarkan tabel 3 dan tabel 7 dapat dibuat grafik aktivitas guru pada kegiatan KKG sekolah melalui workshop untuk setiap siklus, pada saat mengkaji, merevisi/membuat rancangan pembelajaran adalah sebagai berikut:

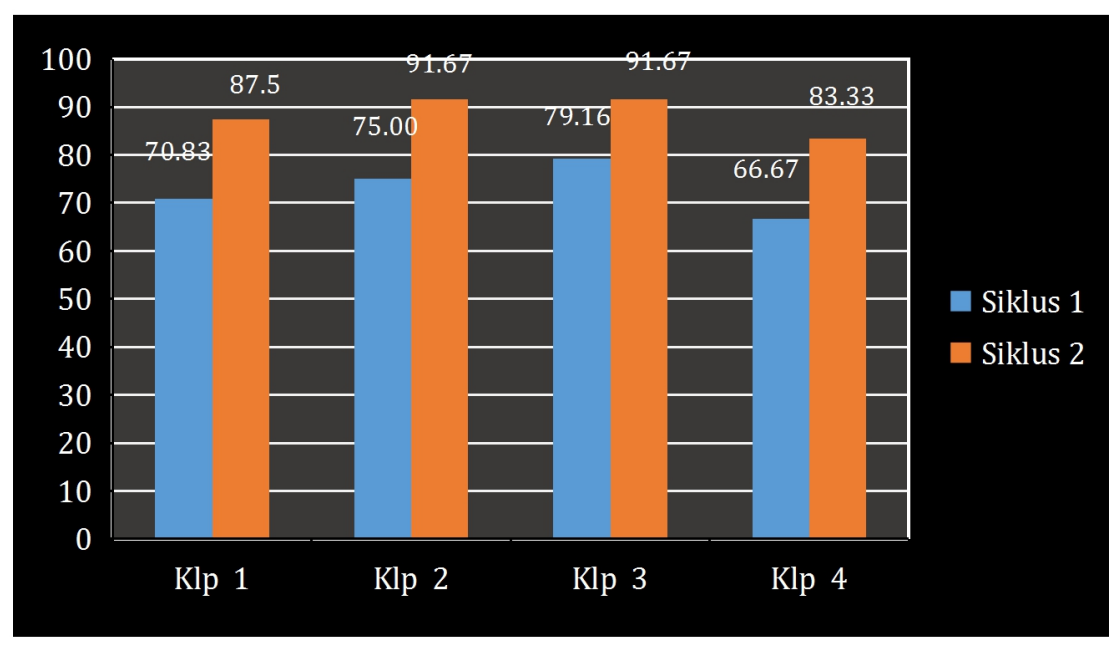

Gambar 2. Aktivitas guru pada siklus 1

Berdasarkan gambar 2 penilaian aktivitas guru mengalami peningkatan dari skor ratarata $72,92 \%$ kategori baik pada siklus I menjadi 88,54\% kategori baik sekali pada siklus II, peningkatan sebesar $15,62 \%$.

Kegiatan KKG sekolah melalui workshop apakah manfaat apakah bermanfaat guru-guru di sekolah. Berdasarkan tabel 4 dan 8 tentang sikap dan minat guru maka dapat digambarkan dalam bentuk grafik sebagai berikut:

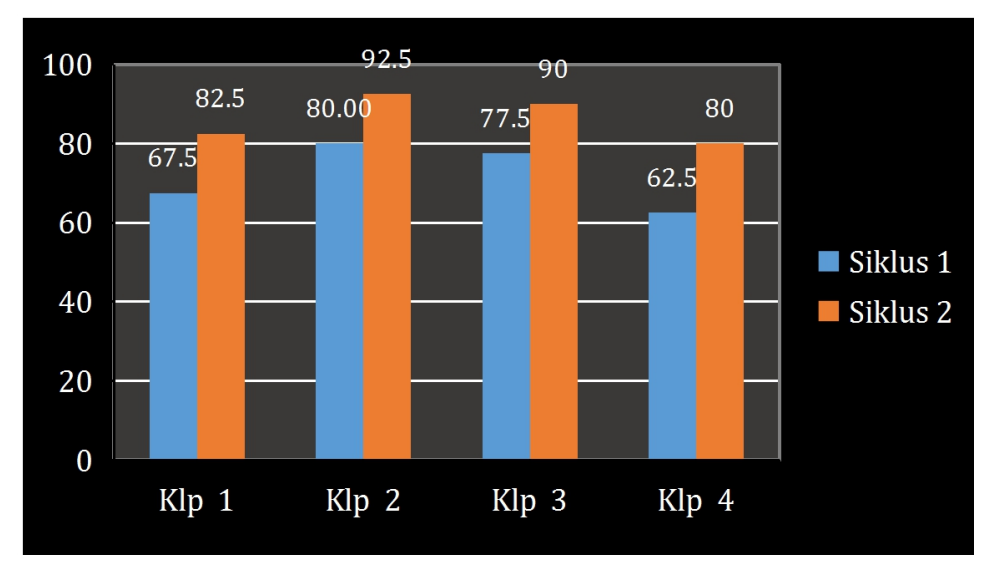

Gambar 4. Sikap dan minat guru pada siklus I dan II

Berdasarkan gambar 4 skor nilai sikap dan minat guru dari 77,88\% kategori baik siklus I menjadi $86.25 \%$ kategori baik sekali pada siklus II, peningkatan skor nilai sikap dan minat sebesar $8,37 \%$. 
Kegiatan bimbingan terhadap guru-guru kelas rendah melalui workshop menghasilkan rancangan pembelajaran antara lain adalah silabus dan RPP yang dapat dituangkan dalam bentuk grafik. Berikut ini grafik produk hasil kegiatan siklus I dan II berdasarkan tabel 5 dan tabel 9 adalah sebagai berikut:

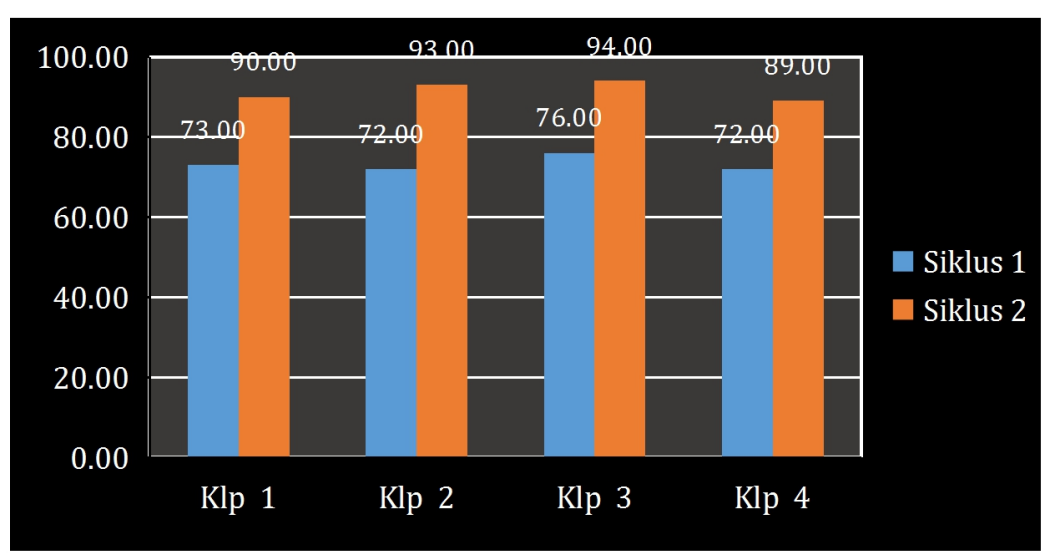

Gambar 5. Hasil evaluasi silabus dan RPP siklus I dan II

Hasil produk workshop berupa Silabus dan RPP pada siklus II mengalami peningkatan kualitas berdasarkan prinsip-prinsip pengembangan silabus dan RPP dari BSNP yaitu pada siklus I rata-rata skor nilai sebesar 73,25 kategori baik pada siklus I menjadi 91,50 kategori baik sekali pada siklus II, berarti terjadi peningkatan sebesar 18,25.

Berdasarkan hasil siklus II maka peneliti menganggap penelitian tindakan sekolah ini telah mencapai hasil sesuai dengan yang diharapkan yaitu terbentuknya komunitas guru kelas rendah yang profesional melalui workshop.

Workshop di KKG sekolah dapat mengefektifkan supervisi akademis diguru baik secara kualitas maupun kuantitas karena dapat memperbaiki kekurangan-kekurangan yang ada dalam rancangan pembelajaran.

Proses pembelajaran yang mendidik pada setiap satuan pendidikan dasar antara lain harus interaktif, inspiratif, menyenangkan, menantang, dan memotivasi peserta didik untuk berpartisipasi aktif, serta memberikan ruang yang cukup bagi prakarsa, kreativitas, dan kemandirian sesuai dengan bakat, minat, dan perkembangan fisik serta psikologis peserta didik (Mashud, 2015). Maka terjadi diharapkan terjadi perubahan secara bertahap pada sekolah, dan dapat melakukannya dengan metode terpadu workshop merupakan aktivitas yang mendorong dan meningkatkan praktek refleksi antara lain: mengembangkan pemahaman bersama, berpendapat dan mendiskusikan praktek pembelajaran, sharing pengalaman belajar bersama, membuat perencanaan pembelajaran bersama, menyusun rencana tindakan bersama serta bersama-sama menganalisis pengalaman pembelajaran.

Berdasarkan beberapa temuan di atas direfleksikan bahwa penelitian dinyatakan berhasil, berarti hipotesis penelitian yang menyatakan bahwa; (a) Jika digunakan kegiatan workshop, maka dapat meningkatkan keterampilan guru dalam membuat rencana pelaksanaan pembelajaran tematik; (b) Jika digunakan kegiatan workshop, maka dapat 
meningkatkan aktivitas dalam membuat rencana pelaksanaan pembelajaran tematik, dapat diterima.

\section{SIMPULAN}

Berdasarkan hasil analisis dari data yang diperoleh, maka hasil penelitian tindakan sekolah pada guru di SDN 1 Landasan Ulin Utara Kecamatan Liang Anggang dengan kegiatan workshop dalam membuat RPP dapat diambil kesimpulan antara lain Hasil penilaian aktivitas guru dalam kegiatan workshop dengan skor rata-rata 72,92\% kategori baik pada siklus I menjadi 88,54\% kategori baik sekali pada siklus II, peningkatan sebesar 15,62\%; Hasil penilaian terhadap nilai sikap dan minat guru dari 77,88\% kategori baik pada siklus I menjadi $86,25 \%$ kategori baik sekali pada siklus II , peningkatan skor nilai sikap dan minat sebesar 8,37\%; Hasil penilaian terhadap produk hasil workshop terhadap silabus dan RPP adalah pada siklus I rata-rata skor nilai sebesar 73,25 kategori baik pada siklus I menjadi 91,50 kategori baik pada siklus II, berarti terjadi peningkatan point sebesar 18,25.

\section{DAFTAR PUSTAKA}

Arikonto, S. 2007. Penelitian Tindakan Sekolah, Makalah disampaikan pada Bimbingan dan

Teknik KTI bagi Jabatan Fungsional Kepala Sekolah. Direktorat PMPTK Departemen Pendidikan Nasional.

Departemen Pendidikan Nasional. 2004. Pemberdayaan KKG. Direktorat Pendidikan Dasar dan Menengah.

Departemen Pendidikan Nasional. 2007. KTI Laporan Hasil Penelitian. Ditjen PMPTK.

Departemen Pendidikan Nasional. 2007. Permen. No. 12. Standar Kepala sekolah Sekolah.

Departemen Pendidikan Nasional. 2007. Permen. No. 16. Kualifikasi guru dan Kompetensi Guru.

Departemen Pendidikan Nasional. 2007. Permen. No. 41. Standar Proses.

Departemen Pendidikan Nasional. 2008. Laporan Penelitian Tindakan Sekolah. Direktorat PMPTK.

Djamarah, Z. 2006. Strategi belajar Mengajar. PT. Rieneke Cipta. Jakarta.

Fathurrohman, P. 2007. Strategi Belajar Mengajar. PT. Rafika Aditama. Bandung.

Mashud, M. (2015). Pendekatan Pembelajaran Pendidikan Jasmani Olahraga dan Kesehatan di Era Abad 21. Jurnal Multilateral, 14(2), 89-196.

https://doi.org/10.20527/multilateral.v14i2.2471.g2172

Purwadarminta. 1983. Kamus Besar Bahasa Indonesia. Jakarta.

Sudijono, 2003. Statistik Pendidikan. Raja Grafindo Persada. Jakarta.

Winardi. 2004. Penelitian Tindakan Kelas. Unversitas Terbuka. Jakarta. 